Pace University

DigitalCommons@Pace

$1-1-2000$

\title{
Abuse of Confidentiality and Fabricated Controversy: Two Proposals
}

John A. Humbach

Elisabeth Haub School of Law at Pace University

Follow this and additional works at: https://digitalcommons.pace.edu/lawfaculty

Part of the Legal Ethics and Professional Responsibility Commons

\section{Recommended Citation}

John A. Humbach, Abuse of Confidentiality and Fabricated Controversy: Two Proposals, Prof. Law., Summer 2000, at 1, http://digitalcommons.pace.edu/lawfaculty/450/.

This Article is brought to you for free and open access by the School of Law at DigitalCommons@Pace. It has been accepted for inclusion in Pace Law Faculty Publications by an authorized administrator of DigitalCommons@Pace. For more information, please contact dheller2@law.pace.edu. 


\section{ABUSE OF CONFIDENTIALITY AND FABRICATED CONTROVERSY: TWO PROPOSALS

\author{
by John A. Humbach ${ }^{1}$
}

The future of the Republic, to a great extent, depends upon our maintenance of Justice pure and unsullied. It cannot be so maintained unless the conduct and motives of the members of our profession are such as to merit the approval of all justmen. ${ }^{2}$

\section{A CRISIS OF PUBLIC CONFIDENCE}

Public faith in the legal profession is not merely low but, according to recent polling, ${ }^{3}$ it has been declining at a disturbing rate. Our profession's unfortunate ethical reputation is not exactly news, of course, but the rapidity of the downward trend is cause for renewed concern. During the past decade the percentage of people willing to rate lawyers' honesty and ethical standards as "high" or "very high" has dropped from $22 \%$ to $13 \%$, an average decline of nearly $1 \%$ per year. ${ }^{4}$ According to the pollsters, lawyers are ranked among "the five professions and occupations considered least honest by the American public," and the legal profession is among the three that had "lost the most in the ratings over the last ten years. ${ }^{16}$ While these polls may not be perfect reflections of public sentiment, it seems safe to say that, in terms of our reputation for ethics and honesty, the past 10 years have not exactly been a decade of progress.

One can, of course, debate the importance of such public opinions. If, however, the old Canons were right, it may be "peculiarly essential" to the long-term stability of our American form of government that the public can trust the lawyers who steward its laws and its justice. ${ }^{7}$ As long as people do not trust the integrity of the lawyers who administer the legal system, they will never find it easy to trust the system as a whole, and the distrust of lawyers runs deep. The documented public cynicism about lawyer ethics and trustworthiness is, therefore, no mere trifling concern. It is a valuable measure of

\footnotetext{
${ }^{1}$ Professor of Law, Pace University School of Law, 78 North Broadway, White Plains, N. Y. 10603 (914-422-4239). Several of the problems dealt with here are also the subject of parallel discussions contained in written testimony prepared by the author for the Ethics 2000 Commission of the American Bar Association and in John A. Humbach, The National Association of Honest Lawyers, An Essay on Honesty, "Lawyer Honesty" and Public Trust in the Legal System, 20 Pace L. Rev. 93 (1999).

${ }^{2}$ American Bar A ssociation CANons of Professional ETHiCs, Preamble (1908) (hereinafter "ABA CANONs").

${ }^{3}$ Leslie McAneny, Nurses Displace Pharmacists at Top of Expanded Honesty and Ethics Poll, Gallup Release of Nov. 16, 1999, available at http://www.gallup.com/poll/releases/pr991116.asp.

${ }^{4} I d$.

${ }^{5} I d$. This ranking on Gallup's "Bottom Five list" was based on the percentages of people who listed the profession as low or very low in terms of honesty and ethics, when asked the question: "Please tell me how you would rate the honesty and ethical standards of people in these different fields - very high, high, average, low or very low? First, ... Next, ... [RANDOM ORDER]." Id. Members of the medical professions were ranked the highest in honesty and ethical standards. Id.

${ }^{6} I d$. As a result of the recent declines, lawyers now have an overall ranking that is just below that of real estate agents and just above that of gun s alesmen. Id. However, contrary to popular myth, lawyers have consistently ranked well above car salesmen, at least since the late $1970 \mathrm{~s}$, surely a point of some distinction. Id. at http:/www.gallup.com/poll/indicators/indhnsty_ethes.asp and http://www.gallup.com/poll/indicators/indhnsty_ethes 2 .asp

${ }^{7}$ ABA CANONs, Preamble.
} 
how well the profession is performing its responsibilities of self-regulation.

Mistrust and the Model Rules-It is doubtful that the legal profession's poor reputation for honesty and ethical standards could be so persistent without some genuine foundation in lawyers' norms of behavior. Yet, most lawyers are actually quite scrupulous (at least in my experience) about observing what they believe is expected of them under the profession's ethical standards. The possibility must therefore be at least considered that there is something about the ethical standards themselves that leads lawyers to act in ways the public finds repugnant.

A principal purpose of this article is to consider the hypothesis that the public's view of lawyers is tied directly to negative reactions people have to two related advocacy norms that seem to be rooted in provisions of the Model Rules of Professional Conduct. ${ }^{8}$ These norms are typically expressed in two particular practices of lawyers, namely: (1) pretending to disagree in the hope that, by not "conceding" a point, the lawyer might get the client an added chance to avoid a legally prescribed liability, sanction, nonsuit or other undesired outcome; and (2) fostering misunderstandings by selectively invoking confidentiality in order to hide material parts of the truth while vigorously (and misleadingly) asserting others. The first of these practices, which I shall call "fabricating controversy," is sometimes described more charitably as endeavoring "to use legal procedure for the fullest benefit of the client's cause." The second, which I shall call "partial-truth advocacy," emerges from a joint reading of the Model Rules on confidentiality and on diligence. ${ }^{11}$

Both of these practices are likely to be stoutly defended by many in the bar, perhaps even as crucial aspects of the adversary system. ${ }^{12}$ At the same, however, neither of these practices would likely be recognized as fully "honest" or "ethical" as those conceptions are generally understood in ordinary, non-lawyer contexts. No one finds it easy to trust people who pretend things in order to get better than they deserve or who induce false understandings by means of partial disclosures and "half-truths." Yet, both of these norms of advocacy behavior are reinforced and propagated by a fair reading of the current Model Rules. Before much progress can be made to rehabilitate our profession's reputation for honesty and ethical standards, it will probably be necessary that the Model Rules themselves be clarified in certain respects.

\footnotetext{
${ }^{8}$ Model Rules of Professional Conduct (1983), as set forth in American Bar Association, Annotated Model Rules of Professional Conduct (4th ed. 1999) (hereinafter "Model Rules"). Adopted in most of the states, the Model Rules contain modifications that vary from state to state.

${ }^{9}$ MODEL RULES, Rule 3.1, cmt. [1].

${ }^{10}$ A fuller and more precise definition of partial-truth advocacy appears in part III "Abuse of Confidentiality," infra.

${ }^{11}$ Model RULes, Rule 1.6 AND Rule 1.3, respectively.

${ }^{12}$ This is a claim of necessity that is, to say the least, debatable. See Joint Conference on Professional Responsibility, Professional Responsibility: Report of the Joint Conference, 44 A.B.A.J. 1158 (1958), reprinted in GEOFFREY C. HAZARD, JR. AND DeBorah L. Rhode, The Legal Profession: Responsibility and REgulation 148-51 (3d ed. 1994) (specifically decrying the misuse of partisan advocacy to mislead, distort or obfuscate, and declaring that a lawyer "trespasses against the obligations of professional responsibilities when his desire to win leads him to muddy the headwaters of decision"). See also Peter C. Kostant, Breeding Better Watchdogs: Multidisciplinary Partnerships in Corporate Legal Practice, 84 Minn L. Rev. 1213, 1215-19, 1253-58 (2000) (observing that the profession's [r]eliance on a flawed model of legal ethics" has led to other serious problems as well, helping to pave the way for competition from so-called multidisciplinary practice firms).
} 
The balance of this article will be framed as a discussion of two proposals for modifying the Model Rules. One would declare fabricated controversy to be out of bounds as a tactical tool. The other would expressly affirm that it is an abuse of confidentiality for lawyers to engage in strategies of partial-truth advocacy, to assert partial truths while deliberately holding back other information that the lawyer should know is needed in order not to mislead others. Both of these techniques, fabrication of controversy and partial-truth advocacy, tend to undercut the trial as a "search for truth" 13 and both interfere with negotiations as a search for fairness in transactions. ${ }^{14}$ Both, moreover, are utilized by lawyers precisely because they undercut and interfere with the intended functioning of these processes. They are resorted to by diligent advocates when factual truth would ill-serve the client's interest at trial, and by diligent negotiators when truthful disclosure would likely prevent a client from getting a deal that the other party would make only if deluded. ${ }^{15}$ Finally, and worst of all, both of these lawyering techniques detract from the legal system's ability to achieve the "gold standard" of justice and the rule of law, viz. the substance of the law applied to the events that actually occur.

\section{FABRICATING CONTROVERSY}

Nothing operates more certainly to create or to foster popular prejudice against lawyers.. . than does the false claim, often set up by the unscrupulous in defense of questionable transactions, that it is the duty of the lawyer to do whatever may enable him to succeed in winning his client's cause. ${ }^{16}$

The first of the two reputation-impairing practices I will discuss is fabricating controversy, the strategic technique of pretending to disagree on issues of procedure or substance in an effort to obtain an ultimate resolution that the client likes better than having "the substance of the law applied to the events that actually occurred." When lawyers fabricate controversy they are making a play on basic features of the dispute-resolution process itself - the costs it imposes on the opponent, the uncertainties it engenders, and the opportunity for lucky accidents that it provides. By raising disingenuous disputes that then require "process" to resolve, a skillful lawyer can exploit the potentials for error that are intrinsic to the process itself and turn those potentials to the client's advantage. Thus, when clients want to escape the law's prescribed liabilities or sanctions for things they have done, or to obtain other unmerited benefits, lawyers have a lawful way to advance these client "interests." By contesting issues on which the parties do not really disagree, a diligent advocate can secure for the client an added chance to "snatch victory from the jaws of defeat."

\footnotetext{
${ }^{13}$ Nix v. Whiteside, 475 U.S. 157, 164 (1986).

${ }^{14}$ See Russell B. Korobkin, A Positive Theory of Legal Negotiation, 88 Georgetown L.J. 1789, 1818-29 (2000), identifying the strategic imperatives of negotiations as agreeing on a single deal-point that allocates "surplus" ("surplus allocation") within the defined range of possible agreements. The result would be an agreement that is mutually beneficial and, in that sense, fair.

${ }^{15}$ The rules do not, of course, permit the lawyer to assist the client in committing perjury or fraud. See MODEL RULES, Rule 1.2(d) and Rule 3.3. But the narrow interpretations of these limitations have left ample leeway for lawyers to make effective use of fabricated controversy and partial-truth advocacy to help their clients escape tight situations. See, e.g., Bronston v. United States, 409 U.S. 352 (1973) (no perjury if witness states the "literal truth"); Schatz v. Rosenberg, 943 F.2d 485 (4th Cir. 1991) (upholding, despite bar's condemnation, assertion of confidentiality rule to conceal information concerning the clients' disastrous financial condition because disclosure by the attorney would probably have caused the other party to reject the clients' promissory notes and guarantees in a sale of corporate securities).

${ }^{16}$ ABA CANONS, Canon 15.
} 
As long as pretended disputations are not frivolous or dilatory, ${ }^{17}$ many lawyers see nothing wrong with such plays on the system's fact-finding imperfections. Nor do they see anything wrong with trying to get their clients better than the clients legally deserve, for example, by avoiding the prescribed consequences for wrongs they have committed. The very fact that many lawyers see things this way is, of course, part of the reason for the public's negative perception of the profession.

The current Model Rules do not seem to condemn these practices, either. The Model Rules do contain provisions that prohibit "frivolous" contentions and dilatory tactics. ${ }^{18}$ However, as we shall see, ${ }^{19}$ these prohibitions apparently do not prevent a lawyer from asserting contentions that have a reasonable likelihood of being upheld, even if the lawyer knows (or reasonably should know) that success in the contention will depend on somebody making a mistake, most likely by inaccurate fact finding. Consider, for example, a lawyer who has confidential information from which the lawyer reasonably should know that the client's cause lacks substantive merit, e.g., the client really committed the tort alleged, but the lawyer nevertheless believes the case can be won. The lawyer may believe it can be won because, for example, the plaintiff's key witnesses are particularly vulnerable on cross-examination or because certain information the plaintiffs need to make their case is almost certainly beyond their reach or, even, unsuspected by them. I dare say few lawyers would maintain that there would be anything frivolous or dilatory about going for victory in such a case. The current Model Rules on frivolous and dilatory contentions would seem to allow it and, arguably, Model Rule 1.3 (Diligence) may even command it. ${ }^{20}$

Nevertheless, to achieve legal victory without substantive merit is not justice, and winnability alone is not a just standard of meritoriousness. To make it clear that the profession's responsibility to justice does not permit lawyers to seize every available legal victory, irrespective of actual factual merit, the Model Rules should contain an explicit prohibition on fabricating controversy, which might read as follows:

A lawyer shall not fabricate controversy or otherwise pretend disagreements by putting a point into contention when the lawyer knows or reasonably should know that there is no real difference between the parties' actual understandings of the facts or applicable law. ${ }^{21}$

Fabricated Controversy is Parasitic to the Basic Function of Legal Process-A lawyer may see a strategic value in contesting a factual point or issue even though, with reasonable investigation, the lawyer should know that the parties have no genuine disagreement on the point or issue. For

\footnotetext{
${ }^{17}$ I.e., as long as they are reasonably well supported by the admissible evidence. See "Fabricated Controversy Distinguished from Merely 'Frivolous' or 'Dilatory' Contentions," infra.

${ }^{18}$ See MODEL RULES, Rule 3.1 (Meritorious Claims and Contentions) and Rule 3.2 (Expediting Litigation), respectively.

${ }^{19}$ See "Fabricated Controversy Distinguished from Merely 'Frivolous' or 'Dilatory' Contentions," infra

${ }^{20} \mathrm{Id}$. There are, for example, relatively recent ethics opinions to the effect that a lawyer can bring an action that the lawyer knows to be time-barred or subject to an affirmative defense - presumably without mentioning the existence of these fatal defects in the client's "cause." See Comm. on Legal Ethics and Professional Responsibility of Pa. Bar Ass'n, Op. 96-80 (1996) (time barred); Legal Ethics Comm. of Or. State Bar, Op. 1991-21 (1991) (valid affirmative defense); see also ABA Formal Opinion 94-387 (disclosure to opposing party and court that statute of limitations has run).

${ }^{21}$ A logical place to insert this new language would be in Model Rule 3.1, just after the current rule's first sentence.
} 
example, even without any underlying disagreement on some factual point the lawyer may still see value in "making them prove it" simply because, on the particular evidence at hand, the lawyer has a reasonable shot at success and success on the point would be to the client's advantage. It may save the client from liability, sanction or other undesired legal consequence. In such situations there is, however, actually only a pretense of controversy. In effect, the lawyer is making a naked play on the legal process, taking a stand in an effort to get a benefit or advantage that the substance of the law does not mean to provide. Similarly, when lawyers invoke procedures, formal requirements or defenses merely because the point seems "winnable" and advantageous, and not because there is any genuine disagreement on the legally relevant facts, the dispute is again only a pretense. Raising the dispute into controversy serves no purpose except to give the client a chance to gain from the process of disputeresolution itself. These pretended disputations are parasitic to the basic functioning of the legal process, which exists to resolve real disputes. They can only add to the system's costs while distracting from its mission, contributing to the public's impression that, with a smart lawyer, a person can escape from the burdens of the law.

The possibilities for pretending disagreement are manifold. Fabricated controversies can be concocted as to matters of procedure or of substance. They may relate to minor collateral points or to the core matters in question. However, whatever the specific context, the reason that fabricated controversies can be successful is generally always the same, namely, like all human systems the law's fact-finding system is not perfect and can make mistakes. The traces left behind by legally relevant events are often fragmentary and conflicting. Witnesses may have background weaknesses that can make cross-examination devastating, even when their direct testimony is fully true. Or a crucial witness may refuse to cooperate, or may fail to appear entirely. ${ }^{22}$ Because of these and other elements of chance that are endemic to the process, skillful advocates can sometimes paint pictures of past events that are very different, legally speaking, from the events that actually occurred, or they can, alternatively, keep the opponent from presenting a picture that is true. It can all be done, moreover, without resort to direct falsehoods or other illegality.

While the discussion that follows here will focus on the litigation context, it bears remembering that the very same sorts of parasitic resort to phony disputation can also occur in the context of transactions. By judiciously raising disputes over this or that issue, a lawyer in negotiations can obfuscate, distract and otherwise create needs for a negotiated "resolutions," so the lawyer's client can then gain extra advantages from the resolutions that result, even when there was no real disagreement in the first place. ${ }^{23}$ This manner of bargaining may be regarded as simply "smart" negotiating tactics, or as underhanded, depending on your point of view.

Winnability vs. Justice-As every lawyer knows, there can be a big difference between being entitled to a legal outcome and being able to prove the facts that the law requires in order to establish that entitlement. This discrepancy between provability and entitlement can be the source of much injustice, and it can occur due to a variety of imperfections in the fact-finding process. For example, as noted in the preceding section, it can occur because one of the parties, due to bad luck or happenstance, simply lacks access to sufficient admissible evidence to prove the truth. It can occur

\footnotetext{
${ }^{22}$ For example, an impecunious insured who is the "client" of an insurance defense lawyer may have no incentive to take part in the defense at all — especially if the policy has been cancelled.

${ }^{23}$ See Korobkin, supra note 14.
} 
because juries and others can make mistakes or be misled-especially if one of the advocates is forcefully pressing a portion of the truth while deliberately concealing the remainder (see "Abuse of Confidentiality," infra). Also, it can occur because parties sometimes are simply unable to afford what it takes to establish facts which, with greater resources, they could readily have proved. Most generally, "imperfections" in the process can be understood to refer to any factor whatsoever whose effect is to allow a party, without violating any law or rule, to prevent the substance of the law from applying to the facts that actually occurred.

Whatever the source of the imperfections, lawyers and their clients may be understandably tempted to take advantage of them when, otherwise, the "law is against them" but they nonetheless desire to obtain a certain legal benefit (e.g., a money judgment) or to avoid a legally prescribed detriment or sanction. So even when there is no real disagreement with other side, and therefore no real "dispute" for the law's dispute-resolution machinery to resolve, they may be tempted to see the machinery itself as an opportunity, a chance for profit. By simply setting the machinery in motion on one or another potentially pivotal point, the lawyer gets an added opportunity to turn defeat into victory by taking advantage of the potential for error, for chance or for other miscarriage that is inherent in legal process. $^{24}$

To some extent these sorts of systemic risks are unavoidable, and it will probably never be possible to eliminate entirely the perennial discrepancies that exist between actual legal entitlements and provability-in-fact - between winnability and justice. This does not mean, however, that the profession should condone conscious efforts by lawyers to seize the fortuitous advantages that may be gleaned from these discrepancies. Sometimes, too, lawyers may simply not know whether their client's cause has substantive merit or not; there may be simply no reason to know whether the underlying facts are in any way different from what the available evidence indicates. It does not, however, follow that lawyers are free to engage in "willful blindness" 25 and pretend controversy in cases where they do have reason to know. On the contrary, if on reasonable investigation a lawyer should know the client's cause is not just, either in whole or in some particular, the ethics of our profession should clearly prohibit the fabrication of controversy in an effort to pretend otherwise. While it may be in the client's "interest" to gain legal advantages or to avoid disadvantages contrary to the substantive intentions of the law, it is not in society's interest or the profession's interest for lawyers to knowingly assist them in these ends. It is

\footnotetext{
${ }^{24}$ Even courts, which are presumably well situated to know, sometimes characterize legal processes as "rolling the dice." E.g.,U.S. Bancorp Mortg. Co. v. Bonner Mall Pshp., 513 U.S. 18, 28 (1994); United States v. Graves, 98 F.3d 258, 260 (7th Cir. 1996); Federated Rural Elec. Ins. Co. v. Arkansas Elec. Coops., 48 F.3d 294 (8th Cir. 1994). "[A] jury determination, unpredictable in the most neutral circumstances." Gertz v. Robert Welch, Inc., 418 U.S. 323,360 (1974)(dissenting opinion).

${ }^{25}$ A term originating in the criminal law field, to deal with people who try to evade mens rea requirements by assuming an ostrich-like attitude toward the facts of what they are doing. See, e.g., United States v. Jewell, 532 F.2d 697 (9th Cir. 1976); W Ayne LAFAve AND Austin SCOTt, CRImINAL LAw 219-220 (2d ed. 1986). Sometimes cited as an instructive example of willful blindness in an attorney is Dr. Johnson's famous reply to Boswell when asked "what he thought of "supporting a cause which you know to be bad'." He said: "Sir, you do not know it to be good or bad till the Judge determines it." See Wong v. Tabor, 422 N.E. 2d 1279, 1286 (Ind. App. 1981). However, as Dr. Johnson made clear, he was not referring to willful blindness with regard to facts but was only reflecting a lawyer's normal cautious agnosticism about future judicial interpretations of law, for he added, flatly: "I have said that you are to state the facts fairly." Id. A good deal of the problem of fabricated controversy emerges, it is submitted, from a maladroit adaptation to contentions of fact of the "winnability" standard of frivolousness, which is more fittingly confined to arguments of law.
} 
to these latter kinds of cases that the above-suggested addition to the Model Rules is meant to apply.

Fabricated Controversy Distinguished From Merely "Frivolous" or "Dilatory" Contentions - The justice effects of fabricated controversies may be reason to deplore them, but a fair interpretation of the current Model Rules seems to allow lawyers to raise issues without any real underlying disagreement as long as there is a reasonable chance of prevailing. The specific Model Rules that come closest to dealing with the question are Rule 3.1 (Meritorious Claims and Contentions) ${ }^{26}$ and Rule 3.2 (Expediting Litigation). ${ }^{27}$ These two rules forbid frivolous and dilatory advocacy, respectively. However, neither of these rules gives reason to think it is ethically wrong to raise an issue or contest a point just because the purpose is to obtain an ultimate outcome that is better for the client than "the substance of the law applied to the events that actually occurred." That is to say, neither gives reason to think it is wrong to controvert a point simply because the goal happens to be to help the client avoid a legally prescribed liability, sanction, nonsuit or other such "merited" unpleasantness. On the contrary, under both of these rules a lawyer is apparently justified in asserting a contention in litigation as long as the point has some chance of being winnable. ${ }^{28}$

The comments to the Model Rules make clear (and the rules themselves leave little doubt) that dilatory refers to contentions raised for purposes of delay, ${ }^{29}$ and that the conception of "frivolous" contentions focuses on actions "primarily for the purpose of harassing or maliciously injuring a person" 30 or contentions that are so obviously without merit there is virtually no likelihood a court would accept them. ${ }^{31}$ In other words, under the Model Rules' conceptions of frivolous and dilatory, a position would be vindicated as non-frivolous and non-dilatory as long as a tribunal reasonably might sustain it. If the law and available evidentiary facts are such that a contention has a reasonable likelihood of being supportable or tenable in court, the contention would not be considered dilatory or frivolous, as traditionally understood. ${ }^{32}$

The adversarial tactic of fabricating controversies or pretending disagreement is, however, very

\footnotetext{
26 "A lawyer shall not bring or defend a proceeding, or assert or controv ert an issue therein, unless there is a basis for doing so that is not frivolous...." MODEL RULEs, Rule 3.1.

27 "A lawyer shall make reasonable efforts to expedite litigation consistent with the interests of the client." MODEL RulEs, Rule 3.2.

${ }^{28}$ See United States v. Edwards, 777 F.2d 364, 365 (7th Cir. 1985) (defining frivolousness in terms of "arguments that cannot conceivably persuade the court"); RESTATEMENT (THIRD) OF THE LAW GOVERNING LAWYERS, $\S 110 \mathrm{cmt}$. d (2000) ("A frivolous position is one that a lawyer of ordinary competence would recognize as so lacking in merit that there is no substantial possibility that the tribunal would accept it"); AMERICAN BAR ASSOCIATION, ANNOT ATED Model Rules of Professional Conduct 300 (4th ed. 1999), citing In re Graham, 453 N.W., 2d 313, 322 (Minn. 1990) ("what the reasonable attorney, considered in light of all his professional functions, would do in the same or similar circumstances"). See also ABA Formal Opin. 94-387 (1994)(lawyer may press a time-barred claim as long as no affirmative misrepresentation is made). Cf. Mareno v. Rowe, 910 F.2d 1043, 1047 (2d Cir. 1990) (for purposes of federal Rule 11, frivolous means no chance of success on law); Wong v. Tabor, 422 N.E.2d 1279, 1287 (Ind. App. 1981 ) (if grounds exist to "support," malicious prosecution does not lie); Tool Research \& Engineering Corp. v. Henigson, 120 Cal. Rptr. 291, 297 (Cal. Ct. App. 1975) (“tenable”); REst ATEMENT (THIRD) OF THE LAw GovERNING LAWYERS, § $57(2)$ and cmt d and Reporter's Note to cmt. d (2000) (liability of lawyer for malicious prosecution), relying heavily on analogous comments in the Second Restatement of Torts, discussed infra note 38.

${ }^{29}$ See MODEL Rules, Rule 3.2, cmt.

${ }^{30}$ See MODEL RULES, Rule 3.1, cmt [2] (last sentence of second paragraph).

${ }^{31} \mathrm{Id}$.

${ }^{32}$ See supra note 28.
} 
different from dilatory or frivolous contentions, as traditionally understood; it is a distinctly unethical way to secure a legal advantage or to avoid a legal disadvantage. Fabricated controversy is not only very different from traditional frivolous or dilatory advocacy but it is systemically much worse. The worst impact of frivolous or dilatory contentions is usually only to cause expense, wheel-spinning and, perhaps, untoward pressure to settle. By contrast, the tactical purpose of fabricated controversy is to try to actually win, despite the fact that a proper substantive predicate for victory is absent. In other words, the fabrication of controversy is a directed effort not just to delay or distract the rule of law but actually to derail it, by inducing a court or others to accept ultimate factual conclusions that neither the lawyer nor the client takes to be true. Indeed, the defining characteristic of fabricated controversy is that a factual (or legal) position is advocated even though it does not correspond to the beliefs about past events or the law that either the lawyer or the client actually holds. ${ }^{33}$ Thus, while alleged instances of frivolous or dilatory contentions can be erased or vindicated by a victory in court, the vice of fabricated controversy is actually enhanced by victory. The fact that the lawyer manages to succeed in fooling a tribunal on a matter of truth does not mean that urging the counterfactual position was legitimate advocacy or that the outcome was just. The fallibility or gullibility of juries, judges or negotiating counterparts is not the test of whether conduct is honest.

It may be objected, of course, that the foregoing description of "frivolousness" is too narrow, and that the Model Rules already prohibit fabricated controversy under the rubric of "frivolous" conduct. This is possible, but it is not likely - and in any case such a prohibition (if it exists) is certainly not very conspicuous. It is true that nothing contained in Rule 3.1 explicitly prevents a person from reading the conception of frivolousness more broadly than the rule's comments suggest, so that it would encompass lawyers' efforts to play the legal process by fabricating controversy. Since, however, Rule 3.1 is, in effect, an exception to the lawyer's core duty to diligently advance the client's interests, ${ }^{34} \mathrm{I}$ think most lawyers would probably regard such a expansive reading to be highly dubious. As long as nothing in Rule 3.1 expressly forbids lawyers from trying to seize the fortuitous advantages that might be gained by plays on the process (as long as this can be done without breaking the law), a lawyer may feel obliged to do so. A lawyer may feel obliged, that is, to bring or defend a proceeding, or to assert or controvert an issue, even when the lawyer knows or reasonably believes that the larger outcome being sought is not merited under the actual facts and applicable law. ${ }^{35}$

The example given earlier of a lawyer who should know, on the basis of confidential information, that the client's tort defense case lacks substantive merit, that the client really committed the tort alleged, is but one kind of case. Situations like this can be multiplied as clients engage lawyers in the hope of avoiding their legal comeuppances for past behavior, imploring their lawyers to "get me out of this." In real life, of course, factual history is often fairly messy, and lawyers many times do not know the

\footnotetext{
${ }^{33}$ See proposed addition to the Model Rules, supra note 21.

${ }^{34}$ See MODEL Rules, Rule 1.3.

${ }^{35}$ The comment to Rule 3.1 specifies that the advocate has "a duty not to abuse legal procedure." MODEL RULES, Rule 3.1, cmt. [1]. It is not, however, obvious that it would be per se an "abuse" of legal procedure for a lawyer to invoke legitimate legal processes to help their clients escape the prescribed consequences of their acts. On the contrary, the comment hastens to specify that "[t]he law, both substantive and procedural, establishes the limits within which an advocate may proceed." Id. (emphasis added). Taken as a whole, the comments to Rule 3.1 do not appear to treat it as an "abuse" of legal procedure for lawyers to invoke it with the conscious object of frustrating others' efforts to prove substantive entitlements to recoveries, defenses, or other legal dispositions, provided only that the lawyer has no purpose to harass or maliciously injure and the lawyer can make a plausible argument for invoking the legal procedure in question.
} 
actual facts with much certainty. Under present Rule 3.1, however, the lawyer has no duty even to try to form a reasonable belief on whether the client's cause is a just one within the intendment of the law. ${ }^{36}$ Thus, the lawyer may fairly conclude from present Rule 3.1 that, in the name of "not being judge-andjury of my own client," the lawyer should adopt a posture of willful blindness, ${ }^{37}$ to "see no evil, hear no evil," so the lawyer can assert with a clear conscience contentions that the actual facts do not support. ${ }^{38}$

The ABA's Ethics 2000 Commission has proposed modifications to Model Rule 3.1 and their proposed modifications would remedy some of these difficulties. Under the proposals, for example, it would be a violation of professional ethics for a lawyer to "bring or defend a proceeding, or assert or controvert an issue therein, unless the lawyer reasonably believes that there is a basis in law and fact for doing so that is not frivolous. ${ }^{39}$ A new proposed sentence in the comments would make clear that "reasonably believes" means a lawyer would at least be expected to investigate and to form a reasonable belief and could no longer resort to willful blindness, as described in the preceding paragraph.

However, the Commission's proposal still would not remedy the distinct problem of fabricated as opposed to merely frivolous or dilatory conduct. In the Commission's proposal, the pivotal criterion for action still centers on the concept of "frivolous," and that concept is still defined in the traditional narrow terms of harassment, malicious injury or machinations that are legally hopeless - too narrow to reach the problem of fabricated controversy. Therefore, the Commission's proposed modifications still would not declare it improper for lawyers to make plays on the system's fact-finding imperfections to avoid or defeat the substance of the law. Lawyers still would be able to say that, under a fair interpretation of Rule 3.1, it is enough to justify asserting a contention in litigation that the point has a chance of being winnable.

\footnotetext{
${ }^{36}$ The duty of competence includes, according to the comments, a requirement that the lawyer inquire into and analyze the legal and factual elements of the problem. See MODEL RULES Rule 1.1. It is certainly not clear, however, that this rule requires lawyers to follow up on leads just because those leads would put a reasonable person on notice that the client's cause or objective is not a just one. That is to say, it is at all not clear that the rules impose any duty whatever for the lawyer ever to try to form a belief of the factual justness (as opposed to plausibility or winnability) of the client's cause or objective.

${ }^{37}$ See supra note 25.

${ }^{38}$ Cf. RESTATEMENT (SECOND) OF TORTS $\$ 674 \mathrm{cmt}$. d (1977), which states: "An attorney is not required or expected to prejudge his client's claim." However, another section of the same Restatement says, inconsistently, that a person does not have probable cause to take an active part in initiating, continuing or procuring civil proceedings unless, among other things, "he reasonably believes in the existence of the facts upon which the claim is based." Id. $\S 675$. This latter section implies that, in order to have probable cause to contest an issue, an attorney must form a reasonable belief as to the merits. While the lawyer is not personally required to actually have probable cause to initiate or continue proceedings (according the to Restatement comments), id. $\S 674 \mathrm{cmt} \mathrm{d}$, a lawyer who acts without probable cause must do so "primarily for the purpose of aiding his client in obtaining a proper adjudication of his claim," id. (emphasis added). However, lack of proper purpose for adjudication exists, for instance: "when the person bringing the civil proceedings is aware that his claim is not meritorious." Id. $\$ 676 \mathrm{cmt}$. c. The same comment adds that a person "cannot believe that the claim is meritorious . . if he realizes that the adjudication will not be in his favor unless the court or jury is misled." Id. The upshot is, then, this: According to the Restatement of Torts, a lawyer may not lawfully proceed in litigation unless the lawyer either (a) reasonably believes that the client's claim is founded on actual facts (probable cause), or (b) actually believes that the client could win without the court or jury being misled as to any matter of fact or law (proper adjudication).

39 Proposed Rule 3.1 - Public Discussion Draft, Ethics 2000 Commission, April 12, 2000, available at http:/www.abanet.org/cpr/rule31.html (new material in italics).
} 
Fabricating Controversies and the Challenge of "Equal Justice"-It is frequently observed that there is a substantial shortfall in legal services to the less well off in our society, and that addressing this shortfall is among the important responsibilities of our profession. However, it is likely that one of the principal contributing causes of this shortfall is our particular vision of the adversary system. One particularly problematic aspect of that vision is the idea that, if a case has a reasonable chance of being won, then the lawyer ought to pursue it with the full force of zealous representation, even if lawyer has "confidential" knowledge that the cause may be substantively unmerited. For instance, according to this vision, a lawyer for a corporation should zealously defend the corporation against a tort claim even if the lawyer confidentially knows that the corporation's employees indeed committed the tort in question, acting in the scope of their employment. Even worse, some prosecutors think they are entitled to bring the full force of the state down on a defendant even when they do not themselves believe the defendant is guilty; they think it is enough to prosecute that a jury can probably be persuaded to convict. ${ }^{40}$ As long as the lawyer believes the case can be won or plausibly defended on the "facts" and law, the current ethic seems to allow (and perhaps, even, require) that the lawyer press for victory as zealously as possible - whatever may be the lawyer's actual private assessment of the basis for the action. Rather than seeing service to justice as being any part of any lawyer's individual ethical responsibility, it is viewed instead as solely and exclusively the responsibility of the system as a whole.

However, this aspect of our particular adversary ethic has especially unfortunate effects when a lawyer's zealous representation skills are unleashed full force against a person who is either poorly represented or not represented at all. It is especially the persons who are in under-represented classes in our society who are likely to be unable to adequately test and rebut the evidence that is mounted against them. It is especially the under-represented who will likely be unable to make the case for prevailing even when, on the law and facts, they should. The problem of "unequal justice" has no simple solution, but it would at least be mitigated if, unlike today, all lawyers had a clear ethical responsibility to refrain from fabricated controversy in situations where they know, or reasonably should know, that their clients should not prevail. By clearly prohibiting the fabrication of controversy, the Model Rules would better assure that the negative effects of the present shortfall of legal services is not exacerbated by the adversary excesses of the legal profession itself.

Summing up the Problem of Fabricated Controversy-To make clear that it is wrong to concoct controversy in the hope of provoking an ultimate legal miscarriage, there must be additional language, beyond the changes proposed by the Ethics 2000 Commission. The Model Rules need an amendment, such as the one suggested above, to make it clear that the adversarial tactic of fabricating controversies, or pretending disagreement on any point of contention, is a distinctly unethical way to secure a legal advantage or to avoid a legal disadvantage. Given the traditionally limited understanding of the frivolousness and dilatoriness concepts, the Model Rules need a specific reference to pretended or fabricated controversy, as set forth in the suggested language above.

\footnotetext{
${ }^{40}$ See Stanley V. Fisher, In Search of the Virtuous Prosecutor: A Conceptual Framework, 15 Am. J. Crim. L. 197, $230 \mathrm{n} 144$ (1988) (stating that, while [c]ommentators differ about whether it is ethical to proceed absent personal belief in the defendant's guilt ... [t] he prevailing view, at least in the world of practice, surely permits prosecutors to do so. See also Bennett Gershman, The Prosecutor's Duty to Truth (forthcoming) (confirming this view among "many prosecutors with whom I have been acquainted over the years," and arguing that prosecutors have a duty to pre-judge the truth of the witnesses and cases they present).
} 


\section{ABUSE OF CONFIDENTIALITY}

The office of attorney does not permit, much less does it demand . . any manner of fraud or chicane. ${ }^{41}$

Lawyer-client confidentiality provides important public benefits, but there are also significant detriments that can flow from its misuse. ${ }^{42}$ When lawyers routinely withhold "damaging" information, their calculated non-disclosures and partial disclosures can foreseeably lead to false understandings in the minds of others. Obviously, it is not the purpose of the lawyer duty of confidentiality to foster false understandings; it is merely an unintended by-product. To make partial disclosures of fact with a purpose to deceive or when material deception is foreseeable, whether it be done in bargaining or in litigation, is an abuse of confidentiality.

In order to preserve the benefits of confidentiality while preventing the detriments and abuses that can occur, a new paragraph (c) should be added to Rule 1.6, as follows:

(c) It is an abuse of confidentiality for a lawyer, in any proceeding or matter, to pursue a strategy or design of selectively revealing information when the lawyer has or claims a duty to conceal other information without which the revealed information would be misleading or deceptive on any issue of material fact.

The purposes of this proposed new paragraph would be to clarify that Rule 1.6 is not intended to foster deception; it would expressly prohibit lawyers from misusing confidentiality as part of stratagems of partial-truth advocacy. "Partial-truth advocacy" means any form of advocacy that is intended to distract from or obfuscate the material facts of a matter, or to cause others to form erroneous conclusions about such facts, by affirmatively stressing part of the truth while asserting a duty to hide other parts of the truth. The proposed new paragraph would declare that lawyers have a professional obligation to refrain from knowingly pressing or advancing half-truths in the representation of clients.

Detriments that Can Flow From Abus es of Confidentiality - Confidentiality is, for many practical reasons, a crucial feature of the lawyer-client relationship. The rule of confidentiality is not, however, an unalloyed benefit to clients, the profession or the system of justice. There is a definite downside every time a lawyer claims an ethical duty to conceal some key part of the truth. The major downside is, of course, that the rule of confidentiality causes otherwise "available" and material information to be withheld from persons who need it to make informed judgments in private matters and to carry out justice in accordance with the law. ${ }^{43}$ Despite the very important objectives that justify confidentiality, its use must therefore be kept in careful balance with the needs of justice, which depends on truth. When truth will bring a client unpleasant consequences, there is obviously a temptation to disguise or conceal. But the law can only apply to the facts that are before it. If the facts are distorted by

\footnotetext{
${ }^{41}$ ABA CANONS 15. "Chicane" means the same as chicanery, i.e., the use of clever but tricky talk or action to deceive, evade, etc. as in legal dealings. Webster's New World Dictionary 243 (3d college ed. 1997).

${ }^{42}$ For further discussion on the general topic, see the excellent economic analysis of Daniel R. Fischel, Lawyers and Confidentiality, 65 U. Chi. L. Rev. 1 (1998).

${ }^{43}$ Concerning the analogous attorney-client privilege, Wigmore wrote: "Its benefits are all indirect and speculative; its obstruction is plain and concrete." 8 JOHN HENRY W IGMORE, EVIDENCE 557 (3D. ED. 1940).
} 
partial truths, so will be the application of the law, and justice will founder.

These negative effects are not, moreover, confined to miscarriages of justice in individual cases. The misuse by lawyers of the rule of confidentiality is no doubt partly responsible for the deep-seated wariness and apprehension that the public feels toward lawyers, for the idea that lawyers deal regularly in half-truths, all too often having something up their sleeves. As surveys cited earlier show, ${ }^{44}$ there is a widespread public impression that lawyers cannot be fundamentally trusted. This distrust is unfortunate not merely for the profession but for the whole justice system. The misuse of confidentiality may sometimes work to the advantage of certain clients, but the advantage is purchased at a high cost. When lawyers misuse confidentiality and deal in partial truths they reduce their credibility overall, a detriment to all of the lawyers' clients. When justice is in the hands of professionals whose full and unstinting fidelity to truth is a matter not merely of doubt but also of abundant grim humor, the effect can hardly strengthen public trust in the rule of law.

The Model Rules should clearly reflect that the proper purpose of confidentiality is not to obstruct the truth; that is only a regrettable by-product. The proper role of the rule of confidentiality is to shield the client, so the client can be open with his or her lawyer without fear that the lawyer might later step forward to bear witness for the adversary. ${ }^{45}$ When, however, a lawyer deliberately adopts and pursues a strategy of partial truth advocacy, of presenting certain evidence while selectively withholding other material evidence, the rule of confidentiality acts not merely as a shield but becomes, instead, a tool of attack. It becomes a device or scheme to distort, deceive and obstruct.

Obstruction is precisely what occurs when a lawyer zealously urges the existence of certain facts while willfully concealing other facts that the lawyer reasonably knows are needed to avoid fostering false or erroneous inferences. Whether the lawyer's immediate purpose is merely to distract from the truth or to distort it, the ultimate goal is the same: to prevent the substance of applicable laws from applying to the facts that actually occurred - to derail the rule of law.

Ordinary Honesty and "Honesty" Under Model Rule 1.6 - As stated in the introduction, most lawyers are rather scrupulous about their ethics and careful to avoid lies; yet the public's distrust of lawyers runs deep. If lawyers seldom lie, why the bad reputation for honesty? The problem is, I think, rooted in a variance of ideas of the very concept of "honesty," a variance that is reflected in the Model Rules. Among the public at large, honesty in not generally understood in merely the cramped and narrow sense that lawyers often have in mind ("no outright lies") but in a far more expansive sense. In this broader sense, an honest person means someone who takes care never to mislead other people. It means a person who does not make it a practice to deliberately hold back crucially pertinent information while trying to persuade others. Foremost, an honest person means one who regards responsibility for the full and complete truth to be the personal responsibility of each and every individual, not as just the collective responsibility of some larger "system."

By contrast, the lawyer's standard of honesty under Rule 1.6 is not nearly as onerous as the

\footnotetext{
${ }^{44}$ See supra notes $3-6$.

${ }^{45}$ Note that, strictly speaking, I refer here only to the ethical duty of confidentiality, not to the evidentiary rule of attorney-client privilege, which shields clients from having their own lawyers be impressed into service as witnesses for the adversary. See MODEL Rules, Rule 1.6, cmt. 5.
} 
general public standard. The lawyer's standard of honesty is instead fitted to a particular conception (albeit not a necessary conception) of the adversary system. In this version of the adversary system, the advocates owe virtually their entire loyalty not to truth but to clients. The assumption behind Rule 1.6 seems to be that the full and open truth is not the personal responsibility of any individual lawyer in particular, but only of the justice system as a whole, a system in which the players may do whatever they can, short of crime or outright lies, to encourage whichever misconceptions happen to serve their cause. If any of the resulting misconceptions need to be corrected, it is up to the adversary to see that the job gets done. Although an ethical lawyer does not lie or help the client to lie, the lawyer has a far more subtle art. By carefully choosing what to disclose and conceal, the lawyer weaves stories that are false out of statements that are true.

By purposely withholding information or willfully undermining accurate but "damaging" evidence, lawyers can frequently cause jurors and others to form misleading impressions of their clients and past events. Most lawyers would probably assert, moreover, that it is not merely the right but the duty of lawyers to bend portrayals of the truth to their client's advantage, even if that means inducing others to fall into mistaken beliefs. When a business client does not want to reveal the whole story in negotiating a deal, it is not the lawyer's job to disturb the false impressions the other side forms as a result. If a guilty client wants to say "I didn't $\mathrm{b}$ it," then that client's non-guilt is the picture of reality the lawyer is expected to convey. In effect, lawyers often encourage others to form conceptions of reality that do not even purport to correspond to the actual facts as either the lawyer or the client honestly sees them.

All of this is done, to be sure, with generally high objectives. There are obviously important values other than truth, and most lawyers surely believe that the false impressions they may convey are in pursuit of those values. However, those values do not include a "right" to obtain legal advantages that are not merited under the actual facts of a case or to avoid legal disadvantages that the law would prescribe if the full truth were revealed. When lawyers succeed in conveying false impressions in the pursuit of unmerited legal advantages or to protect their clients from legal accountability, people feel that justice has been not merely deceived but cheated. And for many outside the profession, that is a problem.

It is not enough to say, in response to these concerns, that "no human system can be perfect." By tolerating misuse of the rule of confidentiality in partial-truth advocacy, the present Rule 1.6 allows the imperfections to be built right into the process, and the public has no trouble seeing this. Almost everyone suspects that the very reason many clients seek legal counsel is to avoid the unpleasant consequences that the law prescribes for cases such as theirs - stated bluntly, to avoid the intent of the law. Some people simply do not want the results that the law provides for the actual facts of their situation, and they think that, with a smart lawyer, "undesired" legal results can be avoided, legally, under the system that we have. And they are right.

The result, however, is a relatively high level of public distrust of lawyers, and that can readily redound to the discredit of the justice system that lawyers maintain. The distrust is not, therefore, a minor tangential annoyance or merely the problem of an insular profession, but it is something that can cut to the heart of the public's basic civic faith in the rule of law. For better or worse, most people probably think the core ideal of justice can only be served if the substance of the law applies to the events that actually occur. The concept of "right" is seen as based on truth, and not merely a matter of who wins regulated competitions to reinvent the past. People expect the law to provide genuinely 
deserved results, not just "due" process.

As long as lawyers in negotiations and advocacy do not even purport to present the full and objective truth as they or their clients honestly see it, no amount of professed concern about values "other than truth" is going to change the declining esteem in which the public holds our profession and the system of justice it maintains and serves.

The Special Problem of the Criminal Defense Context - It may seem hard in the civil context to reach a better balance between the goals of confidentiality and the truth needs of justice, but it may seem virtually impossible to do so in criminal defense. A criminal defendant has, after all, a constitutional right to "effective assistance" of counsel in mounting the defense. ${ }^{46}$ But how can a criminal defense lawyer possibly hope to convince a jury that the defendant is not guilty except by selectively stressing the "helpful" evidence while downplaying or hiding the damaging stuff? Partial-truth advocacy seems integral to the process and, in many cases, the very essence of the game. The fallacy here seems to be the notion that an accused cannot be considered to have received effective assistance of counsel unless the lawyer has tried to assert a full-blown exoneration defense, if that is what the accused wants.

As far as the question of "effectiveness" goes, there does not appear to be any empirical evidence that criminal defendants would be worse off, on the whole, if defense lawyers swore off strategies of selective non-disclosure and partial-truth advocacy. Indeed, innocent defendants (presumably the ones we are most concerned to acquit) would probably be generally better off if criminal defendants were represented by lawyers whose reputations for probity were beyond reproach.

When Chief Justice Earl Warren was a California county prosecutor, he and the public defender developed a relationship of trust that apparently worked to the considerable advantage of the innocent accused. Warren told the public defender that any time he was convinced Warren was prosecuting an innocent person, he should tell Warren so. Then, according to the defender, Warren "would let me look at his files and, if that didn't change my mind, Warren would not prosecute. He trusted me to be as honest with him as he was with me." ${ }^{47}$

What lawyers sometimes seem to forget is that, if criminal defense lawyers are none too trustworthy in their manner of defense, it does none of their clients a service. A person who makes himself generally not believable is one who will not be believed. ${ }^{48}$

For guilty defendants, of course, a believable lawyer may not always be better. In particular, having a lawyer who will not play games with truth may mean it will be hard to put on a successful exoneration defense unless you can successfully bamboozle your own lawyer. This would present a clear drawback for guilty defendants who want to pretend innocence in the hope of getting an unmerited reduction of charge, dismissal or decision not to prosecute. If they tell their honest lawyer the truth the game may be up. By lying, they take the substantial risk of depriving their lawyer of the truthful

\footnotetext{
${ }^{46}$ U.S. CONST . amend. 6.

${ }^{47}$ Leo Kratcher, EARL W ARren: A Political BIOGRaphy 57 (1967).

${ }^{48}$ See Peter C. Kostant, Paradigm Regained: How Competition From Accounting Firms May Help Corporate Attorneys Recapture the Ethical High Ground, 20 Pace L. Rev. 43, 65 (1999) (suggesting that when corporate lawyers behave in untrustworthy ways for one client they breach their fiduciary duties to all their clients by undercutting their own credibility.
} 
information the lawyer may need to get the best deal. Even if this is so, however, it is still not a sound reason for lawyers to try to get judges and juries to swallow versions of past events that they should know are not true. Lawyers should not dishonestly withhold information, pretend controversy or distract from truth just so the guilty can have the aid of counsel to assert a false defense. In a world of honest men and women, the scoundrel may be at a disadvantage, but that does not mean honest people should act like scoundrels in order to compensate.

When all is said and done, it cannot be denied that it would probably be harmful to some criminal defendants if all lawyers eschewed all partial-truth advocacy. It is, however, equally likely that such a change would provide a definite advantage to other defendants, especially those who are innocent or are "not-guilty-as-charged." These latter classes of defendants would almost certainly be better off if their lawyers' presentations could be more readily believed. ${ }^{49}$

Still, it may be objected, there is the Constitution. It secures both a right to effective counsel and a right to make the government prove its case. Thus, the argument goes, unless lawyers can pretend their guilty clients' innocence even when they know the facts, clients will be forced to make an unconstitutional choice: They will forced to choose between their constitutional right to effective counsel and their constitutional right to put the government to its proof.

Putting the matter like this, however, overstates the case. In the first place, "one cannot invoke the Sixth Amendment [right to counsel] as a justification for presenting what might have been a halftruth. ${ }^{950}$ Moreover, there $\dot{\mathrm{s}}$ no suggestion that the rules against involuntary self-incrimination or the requirement of proof beyond a reasonable doubt should not continue to apply in all their force. Even if the defendant's counsel refused to engage in partial-truth advocacy, the government could still be put to its proof. The only suggestion is that a defendant who wants to controvert the government's case would be expected to do so truthfully. ${ }^{51}$ The defendant would not have a "right" to present misleading evidence or knowingly disparage accurate proof in the hope that some undeserved advantage might emerge. The Supreme Court has never held the Constitution to require more than this.

True, the accused has the ultimate authority to decide on whether to plead guilty ${ }^{52}$ and, since the lawyer must abide the defendant's choice, the lawyer has no right to throw in the towel just because the lawyer disbelieves the defendant's plea. What, then, should the honest lawyer do? If the defendant pleads not guilty and firmly professes innocence, the lawyer's posture should be one of constant and resilient suspicion of all incriminating evidence, including any prior admissions by the defendant himself. If, however, the defendant admits guilt in confidence but says to the lawyer "I want to make them prove it," then the honest lawyer's posture of suspicion is modified, to fit the client's own story. While the lawyer should still "mak[e] sure that the prosecution can prove the State's case with evidence that was lawfully obtained and may lawfully be considered by the trier of fact," $"$, it would be dishonest to go so

\footnotetext{
${ }^{49}$ See Humbach, supra note 1, at 112-24 for further related discussion of problem of criminal defense counsel and confidentiality.

${ }^{50}$ United States v. Nobles, 422 U.S. 225, 241 (1975).

${ }^{51}$ Cf. Nix v. Whiteside, 475 U.S. 157 (1986) (stating that the trial is a "search for truth").

${ }^{52}$ See Jones v. Barnes, 463 U.S. 745, 751 (1983); MODEL RULES, Rule 1.2(a).

${ }^{53}$ McCoy v. Court of Appeals, 486 U.S. 429, 434 (1988). Cf. MODEL RULES, Rule 3.1, stating that: "A lawyer for a defendant in a criminal proceeding ... may nevertheless so defend the proceeding as to require that every element of the case be established."
} 
far as to controvert the truthfulness or credibility of witnesses whose testimony agrees with the client's own version of the facts. ${ }^{54}$ In other words, once the state does succeed in sufficiently proving its case with lawfully obtained, admissible evidence whose tenor the defendant does not in fact dispute, then the defendant has received all that he or she is entitled to. If the lawyer were to try to undercut that evidence, even though it is consistent with the defendant's own (confidential) story and the lawyer has no reason to doubt it, then the lawyer would be departing from the "search for truth" and embarking upon a game. It would be, in short, to fabricate controversy.

Similarly, it would be dishonest for a lawyer to present evidence favorable to the client if that favorable evidence would be foreseeably and materially misleading in the absence of other facts that the lawyer is duty-bound to keep confidential. Such an abuse of confidentiality goes beyond the lawyer's duty of "defending the proceeding [so] as to require that every element of the case be established,",55 and enters into the realm of creating alternative realities that are calculated to distract the finder of fact. In short, if the defense lawyer has no truthful alternative story to sell, then the lawyer cannot honestly pretend there is one and, therefore, he or she is effectively consigned to merely testing the government's case. $^{56}$

While the foregoing discussion focuses on criminal defense, it is not meant to imply that prosecutors should not also be subject to comparable, if not even stricter, prohibitions against coyness with the truth. The only reason for stressing the defense context is that certain unique features of that context (defendant's right to plead not guilty, the constitutional right to counsel and the presumption of innocence) make a more extended discussion necessary.

Confidentiality in Federal Criminal Prosecutions-For better or worse, recent developments in federal law suggest that the defense lawyer's duties of candor and full disclosure may, at least in federal prosecutions, already be much broader than typically thought today. Consider, for example, the lawyer's obligations under 18 U.S.C. $\S 1001$, as amended by the False Statements Accountability Act of 1996:

\section{$\$ 1001$. Statements or entries generally}

(a) Except as otherwise provided in this section, whoever, in any matter within the jurisdiction of the executive, legislative, or judicial branch of the Government of the United States,

\footnotetext{
${ }^{54}$ Unless, of course, the lawyer has some independent ground for thinking that the witnesses are in fact lying or erring.

${ }^{55}$ See MOdel Rules, Rule 3.1.

${ }^{56} \mathrm{I}$ have heard the objection that, as a practical matter, a defense cannot be very effective if the jurors are not presented with a credible case for innocence but are told, instead, that the only question for them to decide is whether the government has presented sufficient proof. The thought here seems to be that jurors want to decide the defendant's fate based on their beliefs about who did the crime in fact, not on the basis of a technical legal test. In other words, if jurors truly believe the defendant did it, they are not likely to be impressed by defense arguments that, guilty or not, the defendant should be let go if government's proof is technically insufficient.

However, the very notion that a guilty defendant cannot be convicted except on "proof beyond a reasonable doubt" carries with it the corollary that a real task of fact-finders is to make determinations about the sufficiency of the government's proof--whether it shows guilt beyond a reasonable doubt. To say that jurors cannot be trusted with knowledge of the true nature of their task is to make a serious indictment of the jury system as we know it - claiming in effect that the system must rest on a fundamental deception or else it will not work correctly. It is a claim that $\mathrm{I}$, for one, do not accept. If is the case that defense lawyers in our system cannot "effectively" assist their clients except by presenting half-truths and invented scenarios, then the system is more morally retrograde than I am prepared to concede.
} 
knowingly and willfully-

(1) falsifies, conceals, or covers up by any trick, scheme, or device a material fact;

(2) makes any materially false, fictitious, or fraudulent statement or representation; or

(3) makes or uses any false writing or document knowing the same to contain any materially false, fictitious, or fraudulent statement or entry;

shall be fined under this title or imprisoned not more than 5 years, or both.

(b) Subsection (a) does not apply to a party to a judicial proceeding, or that party's counsel, for statements, representations, writings or documents submitted by such party or counsel to a judge or magistrate in that proceeding. ${ }^{57}$

Notably, § 1001 can apply to any out of court statement in any federal proceeding. Consequently, if a federal prosecutor wants to find out what a defense attorney knows about the facts of a client's case, all that the prosecutor needs to do, it seems, is to ask, with appropriately probing questions. The defense attorney could of course claim privilege and refuse to respond but, if the attorney has a truthful answer that would work favorably for the client, then a refusal to answer promptly could easily harm the client's interest — say, in subsequent plea bargaining. The delayed answer might seem too much like a concocted story when offered up at a later date. Anyway, defense attorneys are ordinarily eager to share exculpatory facts with the prosecution and, indeed, if the defense attorney has a response that would help the client, there would likely be a duty to answer. ${ }^{58}$ That being so, the attorney's claim of privilege would be eloquent in itself, an implicit revelation of the unfavorable or "damaging" information whose existence the prosecutor seeks to confirm. By carefully framing the questions put to defense attorneys, a prosecutor could easily gain at least enough such revelations to shatter a potential pleabargain or, if the attorney's "admissions" got to the jurors, to prevent an acquittal.

Unfortunately, the boxed-in defense attorney has little room to maneuver under $\S 1001$. If the attorney attempts to maintain confidentiality by deflection or other verbal ploys implying lack of knowledge ("I don't know") or by "exculpatory no"-type responses, he or she runs the risk of committing a federal felony under $\S 1001 .^{59}$ The statutory language of $\S 1001$ is very broadly worded in prohibiting such verbal ploys ("conceals, or covers up by any trick, scheme, or device" ${ }^{960}$ ). For its part, the Supreme Court has cast doubt on the possibility that there are any implicit exceptions in $\S 1001$, expressly rejecting the argument (in relation to $\S 1001$ ) that "the Court may interpret a criminal statute more narrowly than it is written." ${ }^{161}$

In short, unless the Supreme Court "finds" an unwritten exception in $\S 1001$ in some future case, the federal defense attorney's ethical duty of confidentiality may already be, in effect, subject to and limited by a duty not to "conceal" or "cover up," imposed by federal law. There is, of course, the constitutional right to counsel, but that right does not include the right to do any thing that would

\footnotetext{
${ }^{57} 18$ U.S.C. $\S 1001$ (emphasis added).

${ }^{58}$ See Model RulES, Rule 1.1 (Competence) and Rule 1.3 (Diligence).

${ }^{59}$ See Brogan v. United States, 118 S. Ct. 805 (1998)(holding that any out-of-court falsehood, even if only in an effort to brush off an accusing question with a denial, is a violation of $\S 1001$ ).

${ }^{60}$ Emphasis added.

${ }^{61} I d$. at 810 . Lest one think it far-fetched that federal prosecutors might start going after defense attorneys, see Terry Carter, Busting the Lawyers: Feds shift drug war from kingpins to criminal defense bar, A.B.A. J., Feb. 2000, at 18.
} 
constitute "violating the law, ${ }^{162}$ and $\S 1001$ is manifestly a law. The only way it might not be "law" is if Congress does not have the constitutional power to make such a modification of the extant contours of lawyer-client confidentiality, as we have come to know them. If not, then $\S 1001$, as applied to lawyers, is unconstitutional. While there is some authority that there may be a degree of sixth amendment rightto-counsel protection for the attorney-client privilege ${ }^{63}$ there is no reason at this point to think today's Supreme Court will hold that the current balance between the rule of confidentiality and the truth needs of justice is written in constitutional stone. ${ }^{64}$

\section{CONCLUSION}

The justice system seeks to influence human behavior by providing various legal advantages and imposing various liabilities whose application depends for the most part on the things that people do. Many times people will see it as personally desirable to seek a legal advantage that is not merited under the law or to avoid a liability that is called for by the law, given the facts of their own particular situation. One effective way to do this is to fabricate controversy in order to make a play on the system and take advantage of the potential for error, for chance or for other miscarriage that is inherent in legal process. Another is to keep the actual facts of past events obscure. With a lawyer who manipulates the facts, a client can escape the intent of the law.

Abuse of confidentiality and fabrication of controversy are both tactics that can play a major role in lawyers' efforts to lead the law to misapply. The fact that many lawyers think it is permissible to do these things in order to help their clients escape the law's intent merely shows that there is a widespread ambivalence toward the actual rule of law. However, the profession's responsibility to justice does not permit lawyers to seize every available legal victory, irrespective of actual factual merit. It does not permit the misuse of confidentiality as a sword that enables advocates to mislead by means of calculated partial disclosures. It does not permit lawyers to fabricate controversy as a strategy to skirt the rule of law. These two techniques may sometimes serve the interests of individual clients, especially those who would be discomfited by full and impartial enforcement, but they bring the profession into disrepute and, therefore, disserve the interests of clients and the nation overall.

In order to strengthen the public's confidence in the justice system we must make it easier than it is now for the public to trust the lawyers who are its custodians. Lawyers should never fabricate controversy as a tactic to derail justice and should never abuse the duty of confidentiality by selectively portraying reality in betrayal of that trust.

\footnotetext{
${ }^{62}$ Nix v. Whiteside, 475 U.S. 157, 166(1986). One must be careful not to overread Nix. It cannot be quite correct to state, as the Court did in Nix, that the lawyer's "overarching duty to advocate the defendant's cause" is "[p]lainly ... . limited to legitimate, lawful conduct." $I d$. at166. Indeed, this statement seems to get things exactly backwards, implying that the constitutional rights of the people are limitable by a legislature's laws. In actuality, of course, it is the other way around, with the legislature's power to make laws being delimited by the Constitution. Accordingly, the threshold question in constitutional cases like $N i x$ is whether the constitutional right to effective assistance of counsel even allows the "law" in question that purportedly limits the lawyer's representation efforts. Even in the case of a law that is as obviously constitutional as the law against suborning perjury (dispositive in Nix), it begs the question to simply assume that the law in question is constitutional.

${ }_{63}$ Neku v. United States, 620 A.2d 259, 262 (D.C. 1993) (applied a balancing test).

${ }^{64}$ See, e.g., Fisher v. United States, 425 U.S. 391, 403 (1976) (stating that the attorney-client privilege applies only where "necessary to achieve its purpose"); United States v. Nobles, 422 U.S. 225 (1975). See also Jones v. Barnes, 463 U.S. at 753 n. 6 ("[T] he fact that the ABA may have chosen to recognize a given practice as desirable or appropriate does not mean that that practice is required by the Constitution").
} 